JOURNAL OF SECURITY AND SUSTAINABILITY ISSUES

ISSN 2029-7017 print/ISSN 2029-7025 online

2019 March Volume 8 Number 3

http://doi.org/10.9770/jssi.2019.8.3(9)

\title{
Scopus
}

\section{THE IMPORTANCE OF SECURITY ASPECTS IN CONSUMER PREFERENCES IN ELECTRONIC ENVIRONMENT}

\author{
Vida Davidavičienè ${ }^{1}$, Jurgita Raudeliūniene் ${ }^{2}$, Manuela Tvaronavičiene் $\dot{e}^{3}$, Justinas Kaušinis ${ }^{4}$ \\ 1,2,3,4 Vilnius Gediminas Technical University, Sauletekio al. 11, Vilnius, Lithuania \\ E-mails: ${ }^{1}$ vida.davidaviciene@vgtu.lt; ${ }^{2 j u r g i t a . r a u d e l i u n i e n e @ v g t u . l t ; ~}$ \\ 3manuela.tvaronaviciene@vgtu.lt; ${ }^{3}$ justinas.kausinis@stud.vgtu.lt
}

Received 18 March 2018; accepted 10 December 2018; published 30 March 2019

\begin{abstract}
Organizations have to face both the opportunities that the technologies provide and the challenges that they create in the local or global market as the consumer behavior in the electronic environment is different from the behavior in an actual shop, therefore it is important to not only understand the changing needs of the customers, the factors that influence their behavior but also to choose suitable strategies while trying to satisfy these needs taking in consideration security issues. For this reason, an important purpose of this study is to indicate the factors that determine the behavior of an e-shop customer by conducting a pilot study in Lithuania. The research identified the key factors of consumer behavior in an e-shop. To establish factors determining the online shop customer preferences, five factor groups were identified on the basis of empirical research: product (service) characteristics, delivery, methods of payment, service quality and web page functionality characteristics. The results of the structured consumer survey showed that the factors that positively influence the decision to buy goods online are lower cost, less time consumption, an ability to make an order at any time of the day, and a larger range of products. The key factors that negatively affect the online shopping are product quality, delivery costs, security aspects, delivery time, and complicated online shopping process. The main problem areas faced by online shoppers were delays in product delivery, product quality, insufficient choice of payment methods, difficult return procedures, too little information about the product. After performing the correlation regression analysis of the structured survey, the following relationships are established: the frequency of online shopping is significantly correlated with the product's compliance with expectations, which indicates that the customers who were satisfied with the quality of online products, more often shop on the Internet.
\end{abstract}

Keywords: behavior; consumer behaviour; e-commerce; behavior influencing factors; multiple criteria assessment

Reference to this paper should be made as follows: Davidavičienè, V.; Raudeliūnienė, J.; Tvaronavičienė, M.; Kaušinis, J. 2019. The importance of security aspects in consumer preferences in electronic environment, Journal of Security and Sustainability Issues 8(3): 399-411. http://doi.org/10.9770/jssi.2019.8.3(9)

JEL Classifications: M1, M15, M16

\section{Introduction}

In the context of global digitalization, various changes take place not only in organizational management structures and processes, but also in fundamental sciences, as the development and application of information technologies create preconditions not only for the emergence and exploitation of the opportunities in the global market but also create certain challenges in order to understand the rapidly changing needs of the users and factors influencing the dynamics of these needs. Scientists differ in their assessment of the specifics of user preferences in the electronic environment, the satisfaction of users' needs and their behavior and the related issues of increasing e-commerce efficiency. Taking into account the fact that the increasing use of the Internet in various fields has greatly expanded the possibilities and speed of access and use of information and, at the same time, has stimulated consumer engagement in a wide range of online activities (such as sharing their opinions on the product/service, providing feedback, comments, recommendations). Research on such issues becomes 
an important starting point for shaping and making informed decisions regarding meeting the changing needs of consumers and increasing the efficiency of the operation of the electronic environment: what kind of website to create, what functions to implement, what products and how to submit, what methods of payment to offer, what sort of delivery solutions to choose to reduce risk, how to enhance consumers trust and security feeling, and so on. To solve these kinds of problems it is important to comprehensively assess the factors determining the behavior of the e-shop user.

A number of research studies of consumer behavior, its components and models have been made in the scientific literature. These models are divided into classical and contemporary models integrating the specifics of the web space. Some of the most popular classical models in the scientific literature are Nicosia, Engel, Howarth - Sheth, which were created under more traditional trading conditions (Engel, Kollat David, \& Blackwell, 1968; Howard \& Sheth, 1969; Thompson, Ravindran, \& Nicosia, 2015). Contemporary models of consumer behavior include black boxes, Solomon, Berkowitz and other models (Berkowitz, Kerin, Hartley, \& Rudelius, 2000; Berkowitz, Kerin 1992; Solomon, Bamossy, Askegaard \& Hoog, 2016). The specifics of consumer behavior models in the electronic environment are analyzed by a large number of researchers (Banyte, Tarute, \& Taujanskytė, 2014; Cheung, Zhu, Kwong, Chan \& Limayem, 2003; Turban, Strauss, \& Lai, 2016; Dębkowska, 2017). However, considering the aspects of consumer behavior studied, the constraints on consumer e-commerce, e-products, e-commerce models in the online environment, there is still a lack of an integrated approach and research to identify the key factors of consumer behavior in e-commerce, especially in terms of the dynamism aspects of the electronic environment.

The study of this type of problem is aimed at identifying factors influencing consumer behavior in the electronic environment, and to identify what kind of security aspects are within this set of factors in the course of a pilot study in Lithuania. To achieve the purpose of the research, such methods as scientific literature analysis, multiple criteria assessment and expert evaluation, structured e-commerce consumer survey, statistical analysis and correlation regression analysis were used.

\section{Theoretical aspects of consumer behavior assessment}

The digital content and its influence on consumers' lives is powerful (Powers, Advincula, Austin, Graiko, \& Snyder, 2012; Limba, Kiškis, Gulevičiūtè, Stasiukynas, Plèta \&Juozapavičiūtè, 2018; Korauš, Gombár, Kelemen, \&Backa, 2019; Benešová \& Hušek 2019). Many scientists (Aghaei, Nematbakhsh, \& Farsani, 2012; Chaffey \& Ellis-Chadwick, 2012; Choudhury, 2014; Hassanzadeh \& Keyvanpour, 2011; Sun \& Wang, 2012; Aghaei et al., 2012; Chaffey \& Ellis-Chadwick, 2012; Choudhury, 2014; Hassanzadeh \& Keyvanpour, 2011; Sun \& Wang, 2012) analyse the development of virtual environment via the web development stages. It should be noted that several aspects during the development had changed: abilities of information transmission, acceptance and processing (from a static information display in stage 1.0 to reading - writing - execution - a parallel processing in stage 4.0), an axis of technologies (from a company to human-computer symbiosis), models of interaction (from stage 1.0 client-server to server-server in stage 4.0), use of information (from development of taxonomies in stage 1.0 to insightful decisions made in stage 4.0 on the basis of information) and technologies used (from static information portals used in stage 1.0 to the opportunities of the Internet of things in stage 4.0). There are different interpretations of cyberspace in the scientific literature (Aghaei et al., 2012; Choudhury, 2014; Powers et al., 2012; Taylor \& Strutton, 2010; Tiago \& Tiago, 2012) starting from a system creating preconditions for people to perceive, communicate and cooperate and finish with the social experience associated with interaction of individuals, exchange of ideas, information sharing, granting of social support, media creation, games, involvement in various discussions and activities using the global network.

Consumer needs and experiences are one of the key elements in decision making processes related to selection of more efficient communication channels and tools for delivering message and achievement of the target audience. Scientists define consumer needs as a desire related to a value that is typical to product or service category in functional and emotional level at a certain time or in a certain situation when a product or service must 
be able to maximize personal consumer benefits, to provide solutions for aesthetic and ergonomic challenges faced by the consumer. Consumer needs can be divided into physical, social and psychological by designating more specific demand groups: family, pleasure, safety, entertainment, shape, sharing, cognition, self-realization (Barnes, Bauer, Neumann, Huber, 2014; Cao et al., 2013; Deci \& Ryan, 2000; Dhir, Chen, \& Nieminen, 2015; Hall \& Zwarun, 2012; Jacobsson \& Wilson, 2014; Lester, 2013; Milyavskaya \& Koestner, 2011; Reinecke, Vorderer, \& Knop, 2014; San \& Yazdanifard, 2014; Taormina \& Gao, 2013). In the presence of certain restrictions in the electronic environment (for example, data protection aspects or potential users are not able to physically touch the product and therefore not always able to assess the quality of the product), it is essential to understand the customer's needs and factors that positively and negatively affect his or her determination to purchase the product, what is directly related with organizational performance. Therefore, both business practitioners and researchers seek to explore and understand the specifics of consumer behavior in cyberspace as a dynamic environment in order to make informed decisions under uncertainty and reduce the risks of various degrees and types. Many researches have stated the behavior of customers and what affects purchase intention online (Ahmed et al. 2017; Barnett, Kwon, \& Stefanone, 2014; Davidaviciene, Pabedinskaitė \& Davidavicius, 2017; Davidavičienè, Sabaityte \& Davidavicius, 2017; Lantos, 2010; Molinillo, Liébana-Cabanillas, \& AnayaSánchez, 2018; Nobar, \& Rostamzadeh, 2018; Raphael, Goldstein, \& Fink, 2017; Saprikis, Markos, Zarmpou, \& Vlachopoulou, 2018; Vo et al. 2017).

Evaluating the innovative products and services of the e-markets, and introducing them into the market, both classical models and additional opportunities created by digitization, such as brand building created by consumers through feedback or personal recommendations on websites, social networks or blogs, have to be taken into account. In order to identify the key factors of consumer behavior in the Internet, an important task is to analyze the classical and contemporary consumer behavioral models proposed by researchers, their peculiarities and factors influencing consumer behavior (1 Table). Analyzing the specifics of consumer behavior in e-commerce, scientific literature examines models of such scientists as Cheung et al. (2003), Laudon \& Traver (2016), Turban et al. (2016). Cheung is one of the researchers who studies the behavior of virtual users. The model describes the categories that affect the virtual user. Cheung combines not only human qualities, but also e-shop, product, demographic, social and environmental criteria and features. The application of the Cheung model can be seen in most online stores, it is quite up-to-date and includes all the main criteria. Nevertheless, there are some shortcomings in this model (Cheung et al., 2003). Laudon and Traver's model is the evolution of the black box, adapting the standard user behavior model to the virtual user behavior model. Additional variables appear as such: company capacity, website opportunities and attendance rates. A positive relationship between using the Internet and online shopping, which means that the more virtual users use the Internet the more they shop online, were observed (Laudon \& Traver 2016). Turban's model delivers a more detailed model of virtual user behavior than Laudon \& Traver (2016) - he also relied on the Black Box model but has significantly expanded it. This model generates a lot of details used in e-commerce: logistics, billing, design, website comprehension, e-mail, call center, FAQ. There is also an agent not described in any model, whose influence on customer selection and purchase is difficult to measure, but its weight is quite high and proven. A very detailed description of personal factors (age, gender, ethnicity, education, etc.), which are very important determinants of the user's choice of product or service, is also there. The Turban model can be compared to Cheung model, which is very similar, paying attention to the finest details and factors. For empirical study Turban model, which outlines the model of virtual user behavior in the most comprehensive way will be taken as base by examining the key points, advantages and disadvantages of e-commerce solutions in consumer behavioral research (Turban et al., 2016). Due to drastic technological changes and new opportunities, previous studies in this field may be limited in their application and new research should be conducted in order to identify new challenges and trends. 
Table 1. Classical and contemporary consumer behavior models

\begin{tabular}{|c|c|c|}
\hline $\begin{array}{c}\text { Name of the } \\
\text { model }\end{array}$ & Model description & Specifics of the model \\
\hline Nicosia model & $\begin{array}{l}\text { The model consists of four parts: communication, information search, } \\
\text { purchasing process, feedback from the user. At the communication stage, } \\
\text { the organization communicates with the customer by emphasizing on the } \\
\text { best product (service) characteristics, price, delivery advantages. At the } \\
\text { stage of the information search, the customer is already familiar with the } \\
\text { organization's product (service) and seeks to receive relevant information } \\
\text { analyzing it by comparing analogues and eventually makes a decision. } \\
\text { If the decision is positive, it moves to the third part of the purchase - } \\
\text { feedback, in which the organization receives data about the purchase, and } \\
\text { the consumer acquires the experience of buying. }\end{array}$ & $\begin{array}{l}\text { Nicosia decision model is more } \\
\text { related with new product purchases } \\
\text { rather than constant purchasing. }\end{array}$ \\
\hline $\begin{array}{l}\text { Howarth - Sheth } \\
\text { model }\end{array}$ & $\begin{array}{l}\text { The essence of the model is repetitive purchases. In Howarth-Sheth's } \\
\text { model the customer is driven by three types of factors: signs, symbols, } \\
\text { and social information. Extended problem solving (strong motivation) } \\
\text { consumer behavior is understood as the active involvement of the customer } \\
\text { in the solution of the problem and the avoidance of risks associated with } \\
\text { the acquisition of the product. Limited problem solving (weak motivation) } \\
\text { customer behaviour describes the passive involvement of the customer. This } \\
\text { model consists of six interrelated components: information and experience, } \\
\text { product type identification, provision, confidentiality, attitude and purchase } \\
\text { action. }\end{array}$ & $\begin{array}{l}\text { The strength of the model is the effort } \\
\text { to identify the links between the } \\
\text { various components. The model is } \\
\text { more promising only after evaluating } \\
\text { the actions of the customer's } \\
\text { recognition of the demand, influenced } \\
\text { by the environment, personal } \\
\text { characteristics and information } \\
\text { accumulated in memory. }\end{array}$ \\
\hline Engel model & $\begin{array}{l}\text { The model concentrates on the user and distinguishes four essential } \\
\text { components: initial stimuli, information rearrangement, decision making } \\
\text { process, and decision variables. Focus is on the customer's decision-making } \\
\text { process. }\end{array}$ & $\begin{array}{l}\text { The benefit of the Engel model } \\
\text { is the focus on the customer's } \\
\text { decision-making process and an easy } \\
\text { implementation of this model, as it } \\
\text { avoids complex links between the } \\
\text { various components. }\end{array}$ \\
\hline Black box model & $\begin{array}{l}\text { The model emphasizes the factors that determine the buyer's willingness } \\
\text { to shop. In it, the marketing (product, price, location, promotion) and } \\
\text { other (economic, technological, political, cultural) incentives fall into the } \\
\text { customer's black box - his consciousness and cause a certain reaction. All } \\
\text { incentives processed in the buyer's black box - his mind, changes into the } \\
\text { choice (of product, name, distributor, time, quantity). The goal of market } \\
\text { analysts is to understand what processes are taking place in the black box } \\
\text { and how the incentive becomes a response. The black box itself consists } \\
\text { of two parts. The first is the characteristics of the customer, influencing } \\
\text { his perception (cultural, social, personal and psychological factors) and } \\
\text { the customer's response to incentives. The second is the buyer's decision- } \\
\text { making process, which influences the behavior of the buyer. }\end{array}$ & $\begin{array}{l}\text { The black box model does not } \\
\text { emphasize repetitive purchases, } \\
\text { loyalty; more emphasis is put on } \\
\text { one-time purchases and the one-time } \\
\text { selection process. }\end{array}$ \\
\hline Solomon model & $\begin{array}{l}\text { The model highlights the social and psychological factors that determine } \\
\text { the consumer's decision to buy, in addition to that it emphasizes the } \\
\text { importance of the purchase situation. }\end{array}$ & $\begin{array}{l}\text { The model puts less emphasis on the } \\
\text { purchase process itself, paying more } \\
\text { attention to the purchase situation, } \\
\text { where the reasons for purchase, time, } \\
\text { environment are already evaluated. }\end{array}$ \\
\hline Berkowitz model & $\begin{array}{l}\text { In the model, with a group of equivalents (psychological, sociocultural and } \\
\text { situational factors) the influence of marketing tools is also distinguished. } \\
\text { The tools of the marketing complex (price, product, promotion and } \\
\text { location) significantly determine consumer behavior and their determination } \\
\text { to purchase the product (service). }\end{array}$ & $\begin{array}{l}\text { The model can be considered to } \\
\text { be one of the most precise and } \\
\text { most complete descriptions of the } \\
\text { consumer's desire to buy. This model } \\
\text { has expanded the contribution of } \\
\text { psychological, socio-cultural and } \\
\text { situational factors to the customer's } \\
\text { decision. Also, this model shows } \\
\text { the buyer's analysis after purchase, } \\
\text { which is already triggering loyalty } \\
\text { and the possibility of a recurring } \\
\text { purchase. }\end{array}$ \\
\hline
\end{tabular}


Having analyzed consumer behavior models, it can be assumed that the models emphasize different aspects of valuation. All models are geared towards personal factors, with the least emphasis on loyalty and re-purchasing. Some models emphasize marketing incentives, others - environmental factors (Table 2). Traditional and virtual user behavior models also have many similarities, as the main object of all models is the user and it is trying to portray the essential stimuli that determine his choice to buy. Because the information in the virtual space is significantly more extensive, respectively, there is more stimuli that can attract more attention from the user, therefore the models are also more comprehensive and focused on case studies.

Table 2. Evaluated aspects in consumer behavior models to be considered

\begin{tabular}{|c|c|c|c|c|c|c|c|}
\hline \multirow[b]{2}{*}{ Model } & \multicolumn{7}{|c|}{ Evaluated aspects } \\
\hline & $\begin{array}{c}\text { Personal } \\
\text { factors }\end{array}$ & $\begin{array}{c}\text { Environmental } \\
\text { factors }\end{array}$ & $\begin{array}{l}\text { Marketing } \\
\text { incentives }\end{array}$ & $\begin{array}{l}\text { Product } \\
\text { qualities }\end{array}$ & Loyalty & $\begin{array}{l}\text { Purchase } \\
\text { situation }\end{array}$ & $\begin{array}{c}\text { Purchase } \\
\text { process }\end{array}$ \\
\hline Nicosia & + & - & + & + & - & - & + \\
\hline Howarth & + & + & - & - & + & - & - \\
\hline Engel & + & + & - & + & - & - & + \\
\hline Black box & + & + & + & + & - & + & - \\
\hline Solomon & + & + & - & - & - & + & - \\
\hline Berkowitz & + & + & + & + & + & + & - \\
\hline Cheung & + & + & + & + & + & + & + \\
\hline Laudon & + & + & + & + & - & - & + \\
\hline Turban & + & + & + & + & + & + & + \\
\hline
\end{tabular}

Source: created by the Authors based on Berkowitz et al., 1992; Engel et al., 1968; Howard \& Sheth, 1969;

Kotler \& Keller, 2011; Solomon et al., 2016; Thompson et al., 2015

Recent research focuses on the aspect of social commerce when reducing the impact of this limiting factor on the sales process. By combining commercial and social factors, social technologies are being developed on e-commerce web sites (Davidavičienè, Pabedinskaitė, \& Davidavičius, 2017; Raudeliūnienè, Davidavičienė, Tvaronavičienè, \& Jonuška, 2018). Social commerce has made it possible to increase mutual communication and collaboration, made it possible to communicate in the online environment ( $\mathrm{Lu}$ et al., 2016). It should be noted that when organizations began to invest in social media, it became increasingly important to identify the specifics of the sales process in the cyberspace as a primary sales channel. There is a tendency that potential consumers agree to pay higher prices for products that are more valuable and more effective in resolving their problems. Studies conducted by Zheng, Yu and Jin (2017) have shown that the attitude of consumers towards the product (service) offered in the context of value depends on the content and intensity of the organization's communication and dissemination of information in social media. Effective communication in the social media between the organization and the user and sharing experience among the users creates the preconditions for changing the consumer's attitude about the quality of the product (service) and the value created, which is directly related to the customer's quick decision to purchase the product (Zheng et al 2017).

Summarizing the results of the research literature, the Turban model (Turban et al., 2016) and its components were chosen for further research, since it describes in detail the model of virtual customer behavior with addition of the loyalty aspect. To establish the factors determining the consumer preferences and the essential consumer requirements for an electronic store, based on empirical research (Cheung et al., 2013; Davidavičienė, Pabedinskaitė \& Davidavičius, 2017; Raphaeli et al., 2017; Raudeliūnienė, Davidavičienè, Tvaronavičienė \& Jonuška, 2018; Saprikis et al., 2018; Tiago \& Tiago 2012; Zheng, Yu \& Jin, 2017), a group of such factors as the product (service) characteristics (assortment, price, description, grouping, comparison, comments, guarantees, promotions, product guide, photos), delivery (delivery speed, price, methods, time, product tracking), payment methods, service quality (consultation, registration, call center, order status management, insurance, warranty, reliability, return connection) and web site functionalities (design, product search, filtering, comments, etc.) were identified. 


\section{Research methodology}

In May and June 2017, a structured survey was carried out on the Internet (involving 4,105 respondents) and an expert evaluation (6 e-business specialists attended) in order to assess the peculiarities of the behavior of Lithuanian consumers in electronic commerce. The structured survey comprised demographic questions related to the respondents (gender, age, education, income), the frequency of buying online, the experience of buying in a foreign online store, the factors influencing the process of the decision to buy online, the advantages and the problem areas when buying online.

A multiple criteria assessment method was chosen to perform the expert evaluation in order to assess the complexity of factors influencing the consumer's decision-making process, the result of a more objective and qualitative assessment. These assessment methods combine the combination of qualitative and quantitative approaches - expert judgment and the use of mathematical analysis methods (Ginevičius \& Ostapenko, 2015; Zavadskas, Turskis, Vilutienè, \& Lepkova, 2017). The expert assessment was attended by 6 experts with more than 10 years of experience in electronic business and having electronic store management competencies. The experts were asked to specify a list of functionalities (product characteristics, service quality, website functionality, methods of payment, delivery of the product) of the e-shop based on empirical research and determine the significance of the factors in the light of the customer preferences in the electronic environment of Lithuania. After performing the expert evaluation, the expert opinion consistency coefficient was calculated, which showed that expert opinions are harmonized.

\section{Research results and discussion}

4105 respondents participated in the structured survey, including 2653 women and 1452 men. The age of respondents was distributed in the following way: $43 \%$ of respondents were $25-35$ years of age, $25 \%$ of $16-24$ years, $17,8 \%$ of $36-45$ years old, and $9,8 \%$ - $46-55$ years and $4,4 \%$ over 56 years old. $49 \%$ of respondents had university education, $31 \%$ had higher non-university education, $15 \%$ had secondary education, $5 \%$ had basic education. $52 \%$ of respondents had an average monthly income of 800 to 1500 EUR, $27 \%$ from 401 to 799 EUR, $11 \%$ more than 1500 EUR and 10\% less than 400 EUR. When assessing the frequency of respondents' online shopping, $66,63 \%$ of respondents shop each month, $29,65 \%$ every three months and 3,72\% - every 6 months or less. The results of the survey showed that $34,4 \%$ of Lithuanian virtual consumers purchase from foreign online stores.

Correlation analysis between purchases in foreign internet shops according to the demographic characteristics of respondents revealed that the purchases between different respondents had a significant difference in demographic characteristics $(\mathrm{p}<0,05)$. The results of the survey showed that foreign internet shops have more male customers who bought there, they are younger than 35 years of age, have higher university education with a monthly income over 800 EUR. 


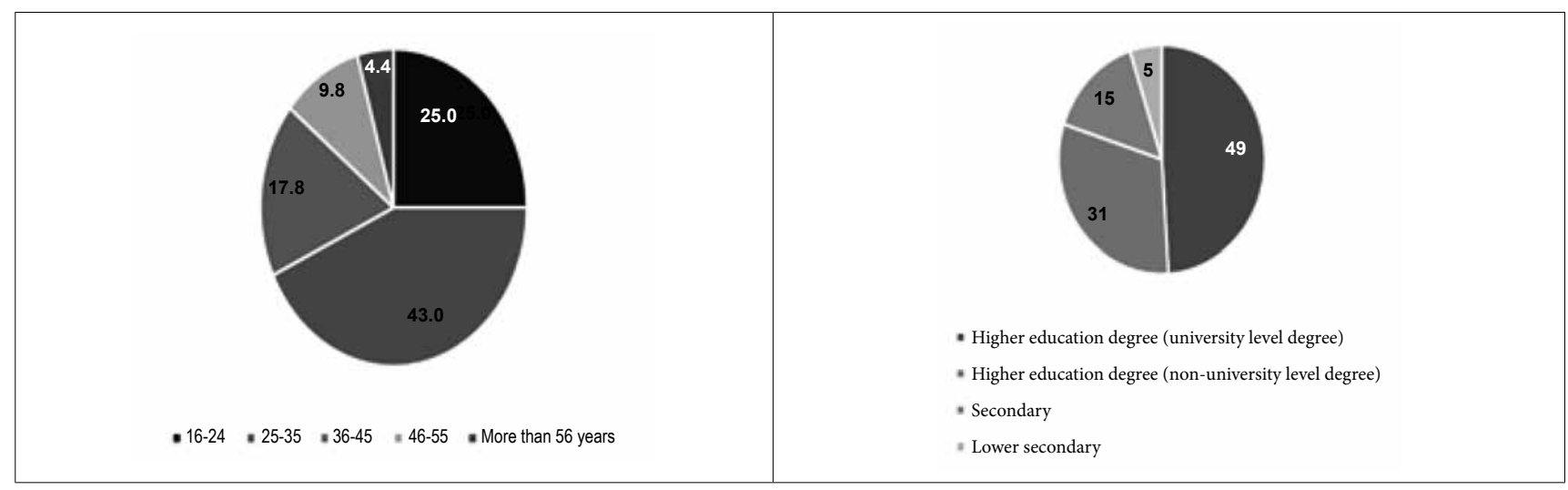

(a)

(b)

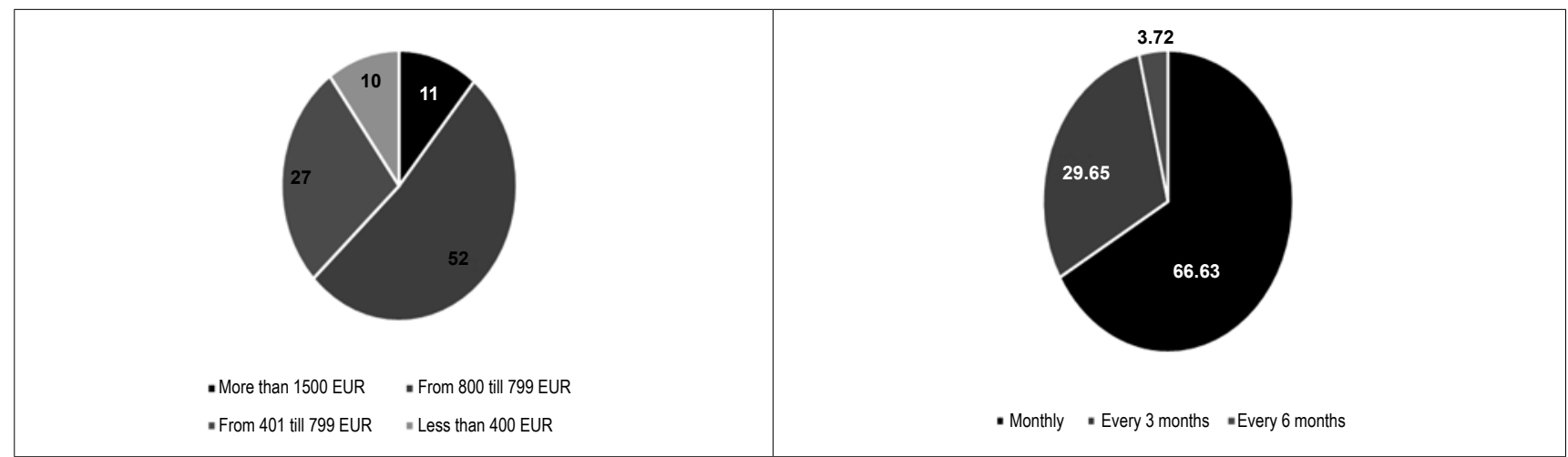

(c)

(d)

Figure 1. (a) Respondents distribution based on their education (percentage); (b) Respondents distribution based on their education (percentage); (c) Respondents distribution based on their incomes per month (percentage);

(d) Respondents distribution based on their online shopping frequency (percentage)

Source: created by the Authors

Based on the correlation analysis and the comparison of the frequency of online shopping by the demographic characteristics of the respondents, the results of the survey showed that women are more likely to buy on the Internet than men, according to their age - those under 45 years, who have a higher education with a monthly income higher than 800 EUR.

The study examined factors that have a positive and negative influence on online shopping decisions and problem areas when shopping online. Respondents indicated that the factors that positively influenced the decision to purchase goods on the Internet were lower prices (38\%), less time consumption (27\%), the possibility of ordering at any time of the day (18\%), and a larger range of goods $(17 \%)$. The main factors that negatively affect online shopping are the quality of the product (it is difficult to evaluate the product quality online) (34\%), delivery price (27\%), security aspects (personal data and material resources) (20\%), delivery time (17\%), complicated purchase process $(2 \%)$. The main problem areas encountered by buyers on the Internet were a delayed delivery of goods $(38 \%)$, product quality (the product received was of poor quality or did not meet the buyer's expectations) (16\%), insufficient choice of payment methods $(16 \%)$, complicated return procedure (15\%), lack of information about the product (15\%). Examining the security aspects of shopping online, it turned out that consumers positively evaluate online help when ordering a product, consulting on product quality, delivery and other issues. A correlation analysis and an online help service in the course of ordering according to the demographic characteristics of the respondents showed that the use of this service is more frequent for women, for persons who are 25 to 55 years of age and those who receive up to 800 EUR per month of income. 
The structured survey also looked at whether the online order was in line with consumer expectations. The obtained results showed that $91 \%$ of users got the items ordered online in line with expectations, $6 \%$ - had no opinion and $3 \%$ of users responded that the items purchased online did not meet their expectations. A correlation analysis showed that the online order was more likely to meet the expectations of men; persons who were 36-55 years of age, with a higher education degree and those with a monthly income of over 800 EUR.

Summarizing the results of a structured survey, it was determined that: the virtual user of Lithuania is educated, of younger age and has higher income; the frequency of online shopping significantly correlates with the purchase in foreign stores $(\mathrm{r}=0,185, \mathrm{p}=0,000<0,05)$ and the correspondence of the product with expectations $(\mathrm{r}=0,074, \mathrm{p}=0,000<0,05)$. This suggests that the consumers buy more often on the Internet as they were satisfied with the product they purchased online.

The second phase of the study aimed at identifying key factors influencing consumer behavior in areas such as product characteristics, service quality, web page functionality, payment methods, product delivery and determining the significance of these factors for the consumer's determination to purchase the product online. Experts have estimated that most consumer preferences are affected by product (service) characteristics $(0.3)$, web page functionality $(0.23)$, product delivery $(0.2)$, service aspects $(0.17)$ and least affecting is the payment method (0.1) (Figure 2a).

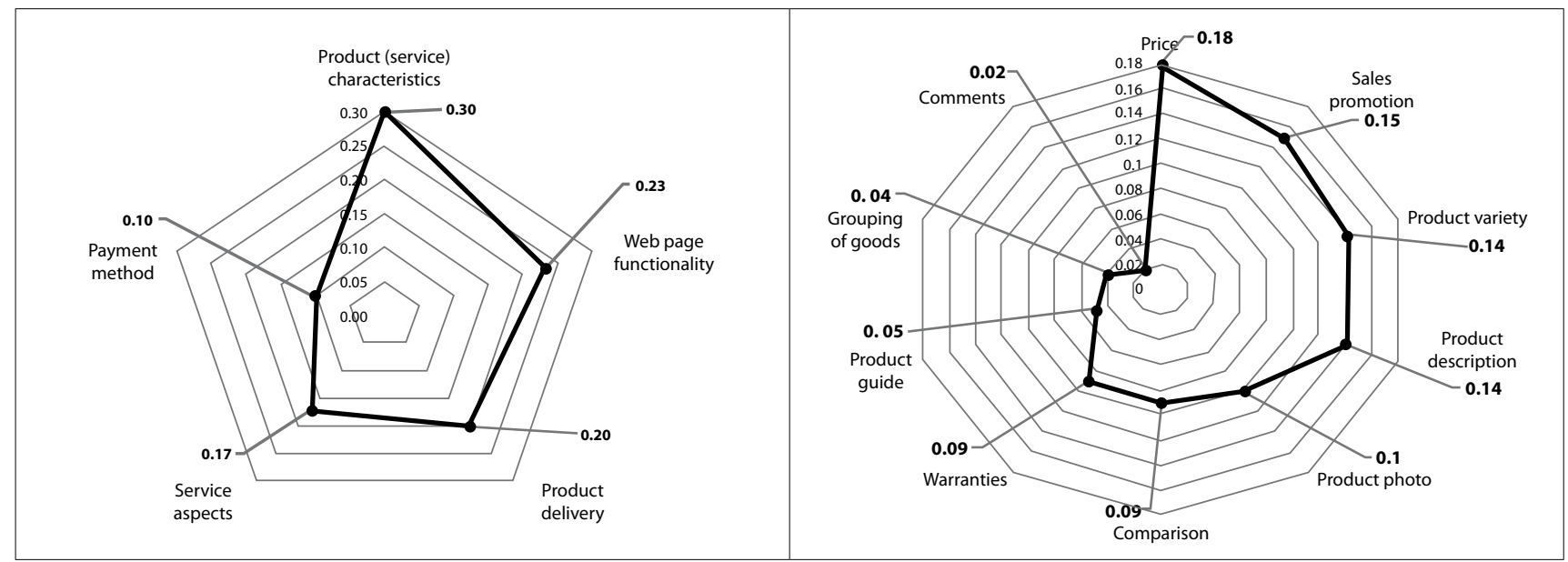

(a)

(b)

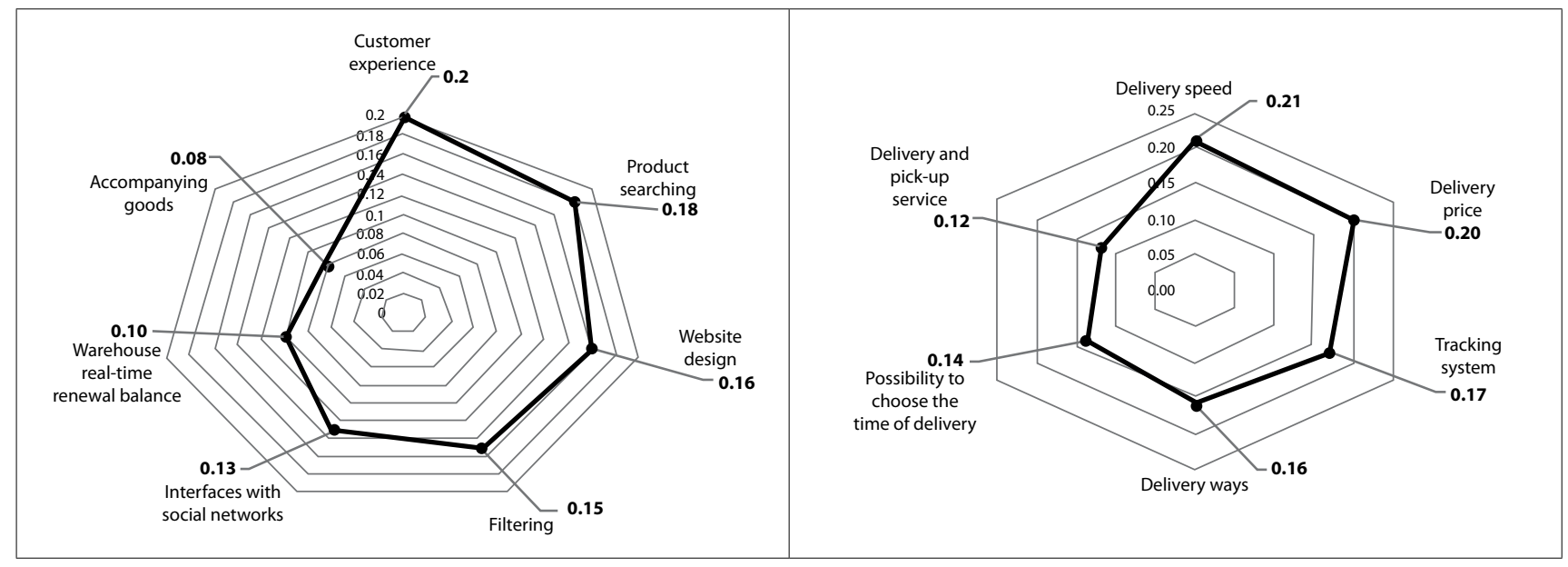

(c)

(d)

Figure 2. (a) Distribution of consumer preferences by groups (expert assessment) on a scale [0, 1]; (b) Distribution of consumer preferences in the product (service) characteristics group; (c) Distribution of user preferences in the web page functionality group;

(d) Distribution of consumer preferences in the product delivery group 
In product (service) characteristics group the main factors influencing the consumer's decision to buy in online store are product price (0.18), sales promotion (0.15), and the least important factors are grouping of goods (0.04) and comments (0.02) (Figure 2b).

The most significant user preferences in the web page functionality group are related to customer experience (recommendations, reviews, evaluation, commentary) (0.2), product searching (0.18) and website design (0.16), and the least significant factor is accompanying goods (0.03). In evaluating this group, experts emphasized the combination of simplicity and functionality, i.e. the simpler the website design with the details to attract the user and the more accurate product search on the website, the less tense the user is when shopping (Figure 2c).

The most significant consumer preferences in the product delivery group are delivery speed $(0.21)$ and delivery price $(0.2)$, while delivery and pick-up service $(0.12)$ is the less important factor. In this group, the experts emphasized the aspect of clarity, the free delivery message should be transmitted very clearly, and if the transport is paid, it must be described in detail so that the consumer does not have to doubt the additional shipping charges. There is a noticeable need for users for different delivery ways and real-time tracking of item shipments in a dynamic environment where user dislocation is constantly changing. Therefore, with the possibility to change the delivery time and delivery location becomes an important aspect (Figure 2d).

In the service aspects group, the most important factors affecting the customer's decision to buy online are reliability (call center, consultation, feedback) (0.6) and management of order status (0.17), but registration (0.06) is less important. Experts in this group distinguished the advantages of reliability (call center, consultation, feedback), management of order status. The online call center, consultation and feedback provide preconditions for increased reliability as the customer can solve his problems live and in time. Also, tracking the ordering of the item and managing the order gives the customer a sense of comfort (Figure 3a).

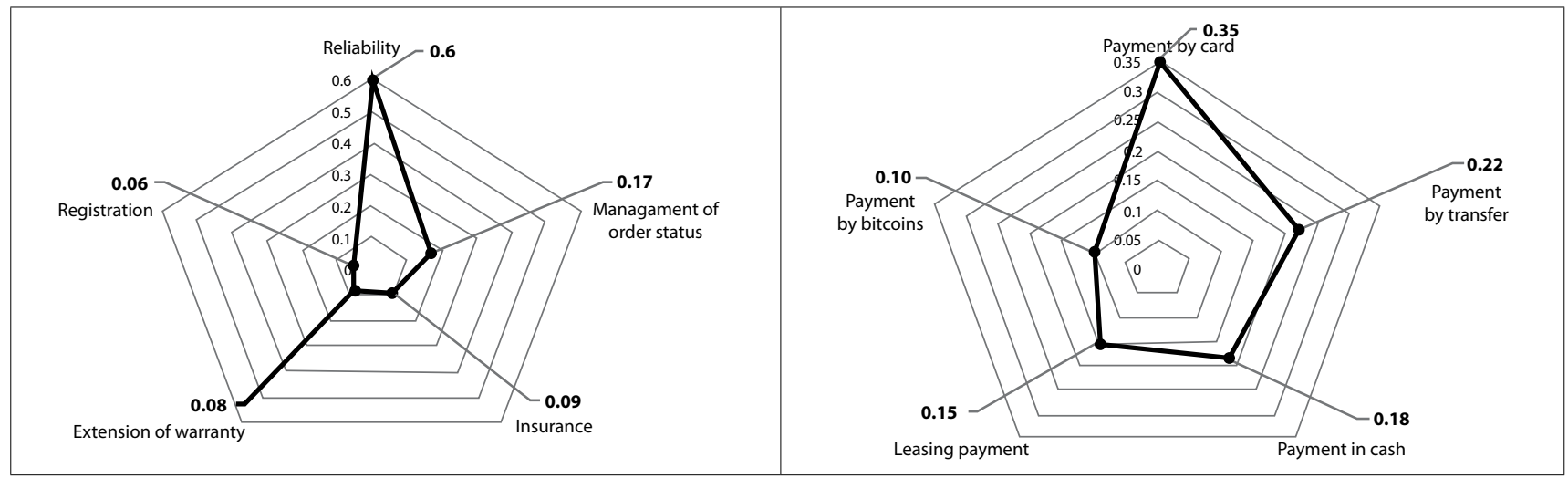

(a)

(b)

Figure 3. (a) Distribution of consumer preferences in the service aspects group (expert assessment) on a scale [0,1]; (b) Distribution of consumer preferences in the payment method group

Source: created by the Authors

In the payment method group, the key factors affecting the customer's desire to buy a product in the e-shop are payment by card (credit, debit) (0.35) and payment by transfer $(0.22)$, while the less important aspect is payment by bitcoins (0.10). Experts pointed out that billing by crypto currency (bitcoin) is very controversial in practice, and its possibilities of growth and end are judged similarly (Figure 3b). 


\section{Conclusions}

After the scientific literature analysis, it can be stated that consumer behavior models have a lot of similarities in both traditional and online commerce. Virtual space models concluded by scientist are based on traditional models, complemented by factors and functionalities that are specific to electronic space. Compared to traditional, the online store has considerably more advantages, but certain advantages of a physical store, such as the ability to evaluate the quality of a product by touching it or take the item home right after payment, still remain. The Turban model (Turban et al., 2016), describing the model of virtual user behavior in more detail, is chosen for further researches after summarizing the results of the research of the scientific literature. To establish factors determining the online shop customer security preferences, five factor groups were identified on the basis of empirical research: product (service) characteristics, delivery, methods of payment, service quality and web page functionality characteristics.

The results of the structured consumer survey showed that the factors that positively influence the decision to buy goods online are lower cost, less time consumption, an ability to make an order at any time of the day, and a larger range of products. The key factors that negatively affect the online shopping are product quality, delivery costs, security aspects, delivery time, and complicated online shopping process. The main problem areas faced by online shoppers were delays in product delivery, product quality, insufficient choice of payment methods, difficult return procedures, too little information about the product.

After performing the correlation regression analysis of the structured survey, the following relationships are established: the frequency of online shopping is significantly correlated with the product's compliance with expectations which indicates that the customers who were satisfied with the quality of online products more often shop on the Internet. Additional help is more often used by the part of customers who less frequently buy in online stores.

Analysis of the results of multiple criteria assessment and expert evaluation has shown that most consumer preferences are affected by product (service) characteristics, web page functionality, product delivery and service aspects. In the product (service) characteristics group the most important factors affecting the customer's decision to buy online are product price and sales promotion. The most significant customer preferences in the web page functionality group are related to customer experience, product search, and website design. The most significant consumer preferences in the product delivery group are delivery speed and delivery price. In the service aspects group, the key factors affecting the customer's decision to buy online are reliability (call center, consultation, feedback) and management of order status. In the payment method group, the most important factors affecting the customer's determination to purchase a product in the online store are payment by card (debit, credit) and payment by transfer.

The results obtained during the study are marked by some limitations, since the study was conducted only in Lithuania. Further research trends could be developed in the following areas: for the purpose of assessing the objectivity and complexity of consumer preferences, to conduct research in a geographically and culturally similar region (for example, by integrating the Baltic region (Lithuania, Latvia, Estonia)); to investigate the relationships between consumer preference evaluation variables and their impact on the organizational performance.

\section{References}

Aghaei, S., Nematbakhsh, M. A., \& Farsani, H. K. (2012). Evolution of the world wide web: from WEB 1.0 TO WEB 4.0. International Journal of Web \& Semantic Technology (IJWesT), 3(1), 1-10. http://doi.org/10.5121/ijwest.2012.3101

Ahmed, R. R., Vveinhardt, J., \& Streimikiene, D. (2017). Interactive digital media and impact of customer attitude and technology on brand awareness: evidence from the South Asian countries. Journal of Business Economics and Management, 18(6), 1115-1134. https:// doi.org/10.3846/16111699.2017.1400460

Asadabadi, M. R. (2016). A Markovian-QFD approach in addressing the changing priorities of the customer needs. International Journal of Quality \& Reliability Management, 33(8), 1062-1075. http://doi.org/10.1108/IJQRM-07-2014-0091 
Benešová, D., Hušek, M. (2019). Factors for efficient use of information and communication technologies influencing sustainable position of service enterprises in Slovakia. Entrepreneurship and Sustainability Issues, 6(3), 1082-1094. http://doi.org/10.9770/jesi.2019.6.3(9)

Banytè, J., Tarutè, A., \& Taujanskytè, I. (2014). Customer engagement into value creation: determining factors and relations with loyalty. Engineering Economics, 25(5), 568-577. http://doi.org/10.5755/j01.ee.25.5.8402

Barnes, S. J.; Bauer, H. H.; Neumann, M. M.; Huber, F. (2014). Segmenting cyberspace: a customer typology for the internet. European Journal of Marketing, 41(2), 71-93.

Barnes, S. J., \& Pressey, A. D. (2011). Who needs cyberspace? Examining drivers of needs in second life. Internet Research, 21(3), 236-254. http://doi.org/10.1108/10662241111139291

Barnett, G., Kwon, H. K., \& Stefanone, M. A. (2014). Social network influence on online behavioral choices: exploring group formation on social network sites. American Behavioral Scientist, 58(10), 1345-1360. http://doi.org/10.1177/0002764214527092

Berkowitz, E. N., Kerin, R. A., Hartley, S. W., \& Rudelius, W. (2000). Interactive Marketing and Electronic Commerce. The McGrawHill Companies.

Berkowitz, E. N., Kerin, R. A., \& W., H. S. (1992). Marketing. Boston: Allyn Bacon.

Cao, H., Jiang, J., Oh, L., Li, H., Liao, X., \& Chen, Z. (2013). A Maslow's hierarchy of needs analysis of social networking services continuance. Journal of Service Management, 24(2), 170-190. http://doi.org/10.1108/09564231311323953

Chaffey, D., \& Ellis-Chadwick, F. (2012). Digital Marketing: Strategy, Implementation and Practice (5th ed.). Pearson Education.

Chai, A., \& Moneta, A. (2012). Back to Engel? Some evidence for the hierarchy of needs. Journal of Evolutionary Economics, 22(4), 649-676. http://doi.org/10.1007/s00191-012-0283-3

Cheung, C. M. K., Zhu, L., Kwong, T., Chan, G. W. W., \& Limayem, M. (2003). Online consumer behavior: a review and agenda for future research. In 16th Bled eCommerce Conference. eTransformation. Bled, Slovenia. Retrieved from https://domino.fov.uni-mb.si/ proceedings.nsf/0/c9beda3ca328c8b7c1256ea1002c72b8/\$FILE/16Cheung.pdf

Choudhury, N. (2014). World Wide Web and its journey from Web 1.0 to Web 4.0. Nternational Journal of Computer Science and Information Technologies, 5(6), 8096-8100.

Davidavičienė, V., Pabedinskaitè, A., \& Davidavičius, S. (2017). Social networks in B2B and B2C communication. Transformations in Business \& Economics, 16(1), 69-84.

Davidavičienè, V., Sabaitytè, J., \& Davidavičius, S. (2017). Features of food industry on the Internet: A case of Lithuania. Challenges for International Business in Central and Eastern Europe, 3(1), 197-209.

Deci, E. L., \& Ryan, R. M. (2000). The "what" and "why" of goal pursuits: human needs and the self-determination of behavior. Psychological Inquiry, 11(4), 227-268.

Dębkowska, K. (2017). E-services in business models of enterprises in the logistics sector. Business: Theory and Practice, $18(1), 79-87$. https://doi.org/10.3846/btp.2017.009

Dhir, A., Chen, S., \& Nieminen, M. (2015). Predicting adolescent Internet addiction: The roles of demographics, technology accessibility, unwillingness to communicate and sought Internet gratifications. Computers in Human Behavior, 51, 24-33. http://doi.org/10.1016/j. chb.2015.04.056

Engel, J. F., Kollat David T., \& Blackwell, R. D. (1968). Consumer behavior. Holt, Rinehart and Winston.

Ginevičius, R., \& Ostapenko, A. (2015). A quantitative evaluation of the company environment for the formation of its effective expansion strategy. Intellectual Economics, 9(2), 130-137. https://doi.org/10.1016/J.INTELE.2016.02.004

Hall, A., \& Zwarun, L. (2012). Challenging entertainment: enjoyment, transportation, and need for cognition in relation to fictional films viewed online. Mass Communication and Society, 15(3), 384-406. http://doi.org/10.1080/15205436.2011.583544

Hassanzadeh, H., \& Keyvanpour, M. (2011). A machine learning based analytical framework for semantic annotation requirements. International Journal of Web \& Semantic Technology (IJWesT), 2(2), 27-38. http://doi.org/10.5121/ijwest.2011.2203

Howard, J. A., \& Sheth, J. N. (1969). The theory of buyer behavior. Wiley.

Jacobsson, M., \& L. Wilson, T. (2014). Partnering hierarchy of needs. Management Decision, 52(10), 1907-1927. http://doi.org/10.1108/ MD-02-2014-0075 
Korauš, A., Gombár, M., Kelemen, P., Backa, S. (2019). Using quantitative methods to identify insecurity due to unusual business operations. Entrepreneurship and Sustainability Issues, 6(3), 1101-1012. http://doi.org/10.9770/jesi.2019.6.3(3)

Kotler, P., \& Keller, K. L. (2011). Marketing management. Pearson.

Lantos, G. P. (2010). Consumer behavior in action: Real-life applications for marketing managers. Routledge. Laudon, K. C., \& Traver, C. G. (2016). E-Commerce 2016: Business, Technology, Society (12th edition). Pearson.

Lester, D. (2013). Measuring Maslow's hierarchy of needs. Psychological Reports, 113(1), 15-17. http://doi.org/10.2466/02.20. PR0.113x16z1

Limba, T.; Kiškis, M; Gulevičiūtè, G.; Stasiukynas, A.; Plèta, T.; Juozapavičiūtè, I. (2018). Model Based on Qualitative Criteria for Internet Marketing Development. Entrepreneurship and Sustainability Issues, 5(3), 618-633. http://doi.org/10.9770/jesi.2018.5.3(15)

Lu, B., Fan, W., \& Zhou, M. (2016). Computers in human behavior social presence, trust, and social commerce purchase intention: an empirical research. Computers in Human Behavior, 56, 225-237. http://doi.org/10.1016/j.chb.2015.11.057

Milyavskaya, M., \& Koestner, R. (2011). Psychological needs, motivation, and well-being: A test of self-determination theory across multiple domains. Personality and Individual Differences, 50(3), 387-391. http://doi.org/10.1016/j.paid.2010.10.029

Molinillo, S., Liébana-Cabanillas, F., \& Anaya-Sánchez, R. (2018). A social commerce intention model for traditional e-commerce sites. Journal of Theoretical and Applied Electronic Commerce Research, 13(2), 80-93. http://doi.org/10.4067/S0718-18762018000200107

Nobar, H., \& Rostamzadeh, R. (2018). The impact of customer satisfaction, customer experience and customer loyalty on brand power: empirical evidence from hotel industry. Journal of Business Economics and Management, 19(2), 417-430. https://doi.org/10.3846/ jbem.2018.5678

Powers, T., Advincula, D., Austin, M. S., Graiko, S., \& Snyder, J. (2012). Digital and social media in the purchase decision process. Journal of Advertising Research, 52(4), 479-489.

Raphaeli, O., Goldstein, A., \& Fink, L. (2017). Analyzing online consumer behavior in mobile and PC devices: A novel web usage mining approach. Electronic Commerce Research and Applications, 26, 1-12. http://doi.org/10.1016/j.elerap.2017.09.003

Raudeliūnienė, J., Davidavičienė, V., Tvaronavičienė, M., \& Jonuška, L. (2018). Evaluation of advertising campaigns on social media networks. Sustainability, 10(4), 1-14. http://doi.org/10.3390/su10040973

Reinecke, L., Vorderer, P., \& Knop, K. (2014). Entertainment 2.0? The role of intrinsic and extrinsic need satisfaction for the enjoyment of Facebook use. Journal of Communication, 64(3), 417-438. http://doi.org/10.1111/jcom.12099

San, Y. W., \& Yazdanifard, R. (2014). How consumer decision making process differ from youngster to older consumer generation. Journal of Research in Marketing, 2(2), 151-156.

Saprikis, V., Markos, A., Zarmpou, T., \& Vlachopoulou, M. (2018). Mobile shopping consumers' behavior: An exploratory study and review. Journal of Theoretical and Applied Electronic Commerce Research, 13(1), 71-90. http://doi.org/10.4067/S0718-18762018000100105

Solomon, M. R., Bamossy, G., Askegaard, S., \& Hoog, M. K. (2016). Consumer Behaviour: a European Perspective (6th ed.). Pearson.

Sun, J., \& Wang, Y. (2012). Global diffusion of virtual social networks: a pyramid model. In Proceedings of the Conference on Information Systems Applied Research (pp. 1-12). New Orleans Louisiana, USA.

Taylor, D. G., \& Strutton, D. (2010). Has e-marketing come of age? Modeling historical influences on post-adoption era Internet consumer behaviors. Journal of Business Research, 63(9-10), 950-956. http://doi.org/10.1016/j.jbusres.2009.01.018

Taormina, R. J., \& Gao, J. H. (2013). Maslow and the motivation hierarchy: measuring satisfaction of the needs. American Journal of Psychology Summer, 126(2), 155-177.

Thompson, N., Ravindran, R., \& Nicosia, S. (2015). Government data does not mean data governance: Lessons learned from a public sector application audit. Government Information Quarterly, 32(3), 316-322. http://doi.org/10.1016/j.giq.2015.05.001

Tiago, M. T., \& Tiago, F. (2012). Revisiting the impact of integrated internet marketing on firms' online performance: European evidences. Procedia Technology, 5, 418-426. http://doi.org/10.1016/j.protcy.2012.09.046

Turban, E., Strauss, J., \& Lai, L. (2016). Social Commerce-Marketing, Technology and Management. Springer International Publishing. http://doi.org/10.1007/978-3-319-17028-2 
Vo, L., Van, Le, H. T., Le, D. V., Phung, M. T., Wang, Y.H., \& Yang, F.J. (2017). Customer satisfaction and corporate investment policies. Journal of Business Economics and Management, 18(2), 202-223. https://doi.org/10.3846/16111699.2017.1280845

Zavadskas, E. K., Turskis, Z., Vilutienè, T., \& Lepkova, N. (2017). Integrated group fuzzy multi-criteria model: Case of facilities management strategy selection. Expert Systems with Applications, 82, 317-331. https://doi.org/10.1016/j.eswa.2017.03.072

Zheng, C., Yu, X., \& Jin, Q. (2017). How user relationships affect user perceived value propositions of enterprises on social commerce platforms. Information Systems Frontiers, 19(6), 1261-1271. http://doi.org/10.1007/s10796-017-9766-y

Vida DAVIDAVIČIENÉ is doctor of social sciences (Management), Professor at Business Technologies and Entrepreneurship Department at Vilnius Gediminas Technical University. She has been involved as an expert in EU and Lithuanian projects (Framework 5th, Leonardo da Vinci, TEMPUS, ERASMUS, COST etc.). Her main research topics include Changes caused by ICT development, currently research concentrates on ICT influence on enterprises transformation in the transition economies. She published more than 80 cientific publications indexed in Web of Science, Scopus, Ebsco, Emerald and other databases, published 1 course book, 2 text books, 7 book (monograph) parts. She is a member of the scientific comities of several scientific journals, and international scientific conferences. She is member of management science board in VGTU.

ORCID ID:

orcid.org/0000-0002-0931-0967

Jurgita RAUDELIŪNIENĖ is a doctor of social sciences (Management), Professor at Vilnius Gediminas Technical University (VGTU), Faculty of Business Management. Her research interests are related to knowledge management, formation and evaluation of strategic decisions, sustainable development. She published more than 50 research papers in scientific journals, actively involved in studies and research projects (Head of VGTU part in projects "Design Lab" (2017-2019), Tempus IV MATRE (2013-2017), researcher in Horizon 2020 (H2020-MSCA-RISE-2014) Cluster Development Med and etc.), member of the scientific and organising committee in international scientific conferences, editorial board member of international scientific journals. She is an expert of Lithuania and Poland Research Councils.

\section{ORCID ID:}

orcid.org/0000-0003-4003-0856

Manuela TVARONAVIČIENÉ is professor at Vilnius Gediminas Technical University of Lithunia. She is national head of European Union's Horizon 2020 research and innovation programme European Research Council (ERC) under the European Union's Horizon 2020 research and innovation programme Marie Sklodowska-Curie Research and Innovation Staff Exchanges ES H2020-MSCARISE-2014 CLUSDEVMED (2015-2019) Grant Agreement Number 645730730.

ORCID ID:

orcid.org/0000-0002-9667-3730

Justinas KAUŠINIS is a Master of Social Sciences at Vilnius Gediminas Technical University, Faculty of Business Management. His research interests are related to consumer behavior in e-commerce. 